This article was downloaded by: [University of Sydney]

On: 05 March 2014, At: 22:03

Publisher: Routledge

Informa Ltd Registered in England and Wales Registered Number: 1072954 Registered

office: Mortimer House, 37-41 Mortimer Street, London W1T 3J H, UK

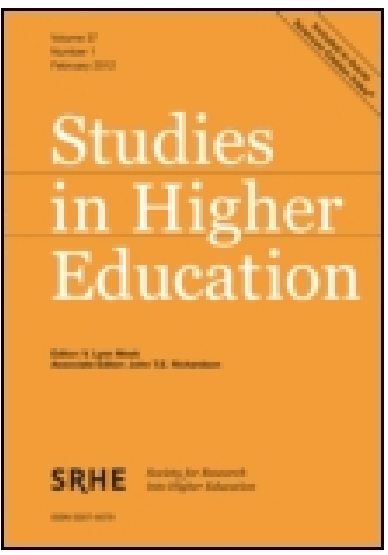

\title{
Studies in Higher Education
}

Publication details, including instructions for authors and subscription information:

http:// www.tandfonline.com/loi/ cshe20

\section{Inquiry-based learning in higher education: principal forms, educational objectives, and disciplinary variations}

Anindito Aditomo ${ }^{\mathrm{ab}}$, Peter Goodyear ${ }^{\mathrm{a}}$, Ana-Maria Bliuc ${ }^{\mathrm{c}} \&$ Robert

A. Ellis ${ }^{c}$

${ }^{a}$ CoCo Research Centre, University of Sydney, Sydney, Australia

${ }^{b}$ Faculty of Psychology, University of Surabaya, Surabaya, East J ava, Indonesia

c Institute for Teaching and Learning, University of Sydney,

Sydney, Australia

Published online: 23 Sep 2011.

To cite this article: Anindito Aditomo, Peter Goodyear, Ana-Maria Bliuc \& Robert A. Ellis (2013) Inquiry-based learning in higher education: principal forms, educational objectives, and disciplinary variations, Studies in Higher Education, 38:9, 1239-1258, DOI: 10.1080/ 03075079.2011.616584

To link to this article: http:// dx.doi.org/ 10.1080/03075079.2011.616584

\section{PLEASE SCROLL DOWN FOR ARTICLE}

Taylor \& Francis makes every effort to ensure the accuracy of all the information (the "Content") contained in the publications on our platform. However, Taylor \& Francis, our agents, and our licensors make no representations or warranties whatsoever as to the accuracy, completeness, or suitability for any purpose of the Content. Any opinions and views expressed in this publication are the opinions and views of the authors, and are not the views of or endorsed by Taylor \& Francis. The accuracy of the Content should not be relied upon and should be independently verified with primary sources of information. Taylor and Francis shall not be liable for any losses, actions, claims, proceedings, demands, costs, expenses, damages, and other liabilities whatsoever or howsoever caused arising directly or indirectly in connection with, in relation to or arising out of the use of the Content.

This article may be used for research, teaching, and private study purposes. Any substantial or systematic reproduction, redistribution, reselling, loan, sub-licensing, systematic supply, or distribution in any form to anyone is expressly forbidden. Terms \& 
Conditions of access and use can be found at http://www.tandfonline.com/page/termsand-conditions 


\title{
Inquiry-based learning in higher education: principal forms, educational objectives, and disciplinary variations
}

\author{
Anindito Aditomo ${ }^{\mathrm{ab} *}$, Peter Goodyear ${ }^{\mathrm{a}}$, Ana-Maria Bliuc ${ }^{\mathrm{c}}$ and Robert A. Ellis ${ }^{\mathrm{c}}$ \\ ${ }^{a}$ CoCo Research Centre, University of Sydney, Sydney, Australia; ${ }^{b}$ Faculty of Psychology, \\ University of Surabaya, Surabaya, East Java, Indonesia; ${ }^{\circ}$ Institute for Teaching and \\ Learning, University of Sydney, Sydney, Australia
}

Learning through inquiry is a widely advocated pedagogical approach. However, there is currently little systematic knowledge about the practice of inquiry-based learning (IBL) in higher education. This study examined descriptions of learning tasks that were put forward as examples of IBL by 224 university teachers from various disciplines in three Australian universities. Data analysis uncovered the principal forms of IBL, the features of each form, their characteristic educational objectives, and possible disciplinary variations. The findings show that underlying the diversity of language and tasks regarded as IBL there is a limited number of distinct task forms and a broad conception of inquiry that is shared by university teachers. The findings also indicate that IBL is practiced in a wide range of disciplines, in both undergraduate and postgraduate coursework programs, in smaller and larger classes, and in universities which are more and less research intensive.

Keywords: learning through inquiry; higher education; teaching practice; educational objectives; survey

\section{Introduction}

Learning through inquiry comes in various guises (Prince and Felder 2007). We use inquiry-based learning (IBL) as an umbrella term covering a range of pedagogical approaches that are united by the central place they give to students' investigative work (addressing questions and solving problems). As a pedagogical approach, IBL is widely recognised and advocated in higher education. The Boyer Commission (1998), for instance, argued that research universities should make IBL the standard pedagogical approach in their undergraduate education. While the Boyer Commission was concerned with teaching practices in research-intensive universities, other scholars have argued that IBL should be mainstream in all universities (Brew 2003; Healey 2005; Spronken-Smith et al. 2007).

While IBL is widely advocated, there is relatively little sustained research on IBL at the university level (Helle et al. 2006; Spronken-Smith et al. 2011). This has begun to change in recent years, as can be seen, for instance, from attempts to develop conceptual frameworks (Healey 2005; Levy et al. 2010; Spronken-Smith et al. 2007); detailed case studies comparing different forms of IBL (Spronken-Smith and Walker 2010); examination of students' experiences of IBL (Ellis et al. 2007; Ellis et al. 2005; Levy and Petrulis 2011); and impact on student learning outcomes (Justice, Rice, and Warry 2009).

\footnotetext{
*Corresponding author. Email: aadi4954@uni.sydney.edu.au
} 
Nonetheless, there has been little work that sheds light on the variations in how IBL is employed in higher education. Many of the relevant works have been case studies of specific instances of IBL (e.g. Andrews and Jones 1996; Justice et al. 2007; Oliver 2008; Rogers and Abell 2008; Spronken-Smith et al. 2011). One exception is Jewell and Brew's (2010) study, which examined extra-curricular research programs in universities in Australia. These authors found that such research programs were offered in 23 of the 39 universities, that the programs concentrated more in the science and technology disciplines, and that they tended to target an elite segment of the undergraduate student population. Jewell and Brew's study focused on a very specific type of inquiry: one in which students are paid and conduct formally supervised research. This focus excludes other forms of IBL that may be practiced by university teachers. Hence, we currently have little systematic knowledge about the kinds of tasks that university teachers regard as being inquiry-based, the principal variants or forms of IBL that are employed, or the educational objectives that teachers intend to achieve through IBL.

To address this issue the present study examines the descriptions of IBL tasks employed by a sample of 224 teaching academics from a broad range of disciplines. The study maps the varieties and features of tasks that university teachers regard as being inquiry-based. This can shed light on variations in what counts as IBL and enhance the clarity of discussions among researchers, teachers, educational developers, curriculum leaders, managers and policy makers. Investigating the features of different forms of IBL can also provide a starting point to address concerns held by some university teachers, such as the concern that IBL may not be suitable for first/second year students, or that IBL can only be used in very small classes. This mapping can also help identify possible disciplinary patterns, which can be useful for understanding discipline-specific ways to foster the research-teaching nexus through IBL (Healey 2005).

To set the stage for our findings and discussion, we present a brief review of how IBL has been described in the literature.

\section{Definitions of IBL}

Various definitions of IBL have been proposed. Levy et al. (2010, 6), for instance, defined IBL as 'a cluster of strongly student-centred approaches to learning and teaching that are driven by inquiry or research'. Speaking of 'inductive teaching', Prince and Felder $(2007,14)$ defined it as teaching that begins by 'presenting students with a specific challenge, such as experimental data to interpret, a case study to analyze, or a complex real-world problem to solve'.

Similarly, Oliver $(2008,288)$ described IBL as teaching approaches in which 'some form of problem or task serves as a catalyst for student engagement and participation $[\ldots]$, learning comes as a consequence of the information processing that occurs as students work to explore the problem setting and to seek a solution.' According to Justice et al. $(2007,202)$, IBL refers to 'a range of instructional practices that promote student learning through student-driven and instructor-guided investigations of student-centred questions'. Spronken-Smith et al. (2007) proposed the following as core elements of IBL: it should be driven by questions or problems; based on seeking new knowledge and understanding; and student-centred and -directed, with teachers acting as facilitators. 
While they differ, the definitions above share at least one common element: that IBL is question- or problem-driven. Implicitly, this entails students' performing investigations of some sort to address questions or solve problems. This conception serves as the basis of our analysis. On the one hand, the conceptualisation of IBL as being a learning activity that is question- or problem-driven is broad enough to encompass a range of more specific pedagogical approaches. On the other hand, the definition excludes teaching approaches which are primarily concerned with the exposition of content or of a topic.

Beyond agreeing on this broad conceptualisation, we need a method for organising the diversity of IBL. There are two main ways to do this: by proposing a small number of 'principal forms', and by identifying key dimensions along which specific instances can vary.

\section{Forms of IBL}

Some authors have proposed that many forms of IBL can be grouped under the headings of problem-based, project-based, and case-based teaching (Mills and Treagust 2003; Prince and Felder 2007). These approaches may have different historical origins (e.g. classical problem-based learning originates in medical education, whereas case-based teaching is seen as originating in business education). They are also said to have certain unique characteristics. Table 1 gives a summary of how these three forms of IBL are commonly described in the literature.

One can add other approaches to this list - such as traditional science laboratory activities, work for a dissertation or thesis, and also newer approaches such as knowledge-building (Scardamalia and Bereiter 2006). Hence, the list may grow and change over time. In principle, one might also expect a list of IBL forms to vary across

Table 1. Problem-based, project-based and case-based teaching/learning.

\begin{tabular}{|c|c|c|c|}
\hline Aspect & Problem-based learning & Project-based learning & Case-based teaching \\
\hline $\begin{array}{l}\text { What provides } \\
\text { structure }\end{array}$ & $\begin{array}{l}\text { Starts with a real world } \\
\text { problem which is } \\
\text { unstructured, open- } \\
\text { ended, and thus needs } \\
\text { to be refined before it } \\
\text { can be addressed. }\end{array}$ & $\begin{array}{l}\text { Starts with clear } \\
\text { specification of an } \\
\text { end-product that is } \\
\text { usually tangible. }\end{array}$ & $\begin{array}{l}\text { Starts with (usually) } \\
\text { real case narratives } \\
\text { that are written to } \\
\text { exemplify how } \\
\text { concepts/theories can } \\
\text { be applied. }\end{array}$ \\
\hline Typical process & $\begin{array}{l}\text { Students are responsible } \\
\text { for refining the } \\
\text { problem, and also } \\
\text { identifying what they } \\
\text { need to know and } \\
\text { how to bridge any } \\
\text { knowledge-gaps. }\end{array}$ & $\begin{array}{l}\text { In working to produce } \\
\text { the desired product, } \\
\text { students encounter } \\
\text { 'mini-problems' } \\
\text { which need to be } \\
\text { solved. }\end{array}$ & $\begin{array}{l}\text { Students usually } \\
\text { discuss cases in } \\
\text { groups. They analyse } \\
\text { cases and answer } \\
\text { questions already } \\
\text { composed by the } \\
\text { teachers. }\end{array}$ \\
\hline $\begin{array}{l}\text { Pedagogical } \\
\text { emphasis } \\
\text { and purpose }\end{array}$ & $\begin{array}{l}\text { Emphasis is on the } \\
\text { process of solving the } \\
\text { problem; the main } \\
\text { purpose is to acquire } \\
\text { new knowledge. }\end{array}$ & $\begin{array}{l}\text { Emphasis is on the } \\
\text { product of the } \\
\text { activity; the main } \\
\text { purpose is to practice } \\
\text { applying knowledge. }\end{array}$ & $\begin{array}{l}\text { Emphasis on process of } \\
\text { analysing cases; the } \\
\text { main purpose is to } \\
\text { acquire new } \\
\text { knowledge. }\end{array}$ \\
\hline
\end{tabular}

Source: Based on Mills and Treagust (2003), Helle, Tynjala, and Olkinuora (2006), Savery (2006) and Prince and Felder (2007). 
disciplines or levels of education, or between research-intensive and other universities, although there is little data on any such patterns.

Key terms can and have been used in different ways. The way these terms are used in teachers' discourse may not conform to normative definitions in the scholarly literature. For instance, practices labelled as problem-based learning are often much more structured than in the classical medical forms of PBL (Savery 2006). People might also use other labels to describe instructional practices that have the defining features of one of the approaches above. For instance, the 'Learning by Design' approach (Kolodner 2006; Kolodner, Gray, and Fasse 2003) fits nicely as an instance of project-based learning. Consequently, it becomes difficult to fix the essence of each term.

\section{Key dimensions of IBL}

Another way to organise the diversity of IBL is by identifying key dimensions along which specific instances may vary. Spronken-Smith and colleagues (2007) pointed out two dimensions: (temporal) scale, and the level of structure embedded in an inquiry task. The scale of inquiry tasks can range from (a) being contained in a single lecture or tutorial session, through (b) running across a number of lectures in a single courses, to (c) degree or program-wide. In terms of level of structure, an inquiry task can be structured (where both the inquiry problem/question and procedures are provided by the teacher), guided (where the teacher provides broad direction and guidelines), or open (where students must construct their own questions/problems and ways of addressing them).

Discussing ways in which research and teaching can be linked, Healey (2005) proposed another pair of useful dimensions: student-centeredness and focus of activity. With respect to the former, an inquiry task may position students as an audience, or as active participants. On the latter dimension, an inquiry task may focus on research content, or it may focus on research process and problems. Using these dimensions, Healey and Jenkins (2009) distinguished four approaches through which students can engage with research: a) Research-led (students as audience, focus on learning about current research); b) Research-oriented (students as audience, focus on developing inquiry skills); c) Research-tutored (students as participants, engaged in discussion about content of current research); and d) Research-based (students as participants, performing research/inquiry). It is the latter approach (Research-based tasks) that Healey and Jenkins consider to be a form of inquiry-based learning.

Complementing the above dimensions, Levy and colleagues (2010) proposed the dimension of learning goal. Thus, an inquiry may seek to help students learn about existing knowledge, or it may challenge students to produce new knowledge. This dimension, combined with the distinction in the source of the inquiry problem, creates a matrix of four modes of inquiry: a) Authoring (inquiry seeking new knowledge to address students' own question/problem); b) Producing (inquiry seeking new knowledge to address question/problem posed by teachers or clients); c) Pursuing (inquiry to explore existing knowledge about students' own question/problem); and d) Identifying (inquiry to explore existing knowledge about question/problems posed by the teacher) (Levy and Petrulis 2011).

These frameworks help capture nuances in the broad spectrum of IBL. In the present study, we utilised some of these dimensions (e.g. whether students are expected to produce new knowledge) to characterise the IBL tasks. While we adopted and used 
some dimensions in a top-down fashion, we have also examined how well these dimensions capture the diversity of IBL tasks that can be observed in our data.

\section{Educational objectives associated with IBL}

One class of learning objectives associated with IBL has to do with metacognitive skills. For instance, some authors cite developing students' metacognitive knowledge and self-regulated learning (SRL) skills as intended outcomes of IBL (Justice et al. 2007; Spronken-Smith and Walker 2010). These goals are often mentioned together with cognitive skills such as critical thinking and problem solving. Some authors also relate these goals with affective dimensions such as 'love of learning' (Justice, Rice, and Warry 2009) and appreciation of concepts and theories (Prince and Felder 2007).

Another class of educational objective often associated with IBL is related to inquiry or research capabilities. For instance, the Boyer Commission (1998, 13) described IBL as capable of developing in students 'a spirit of inquiry'. Justice and colleagues $(2007,203)$ wrote that inquiry can promote students' ability 'to think critically and reflectively about the production of knowledge'. In a similar vein, Spronken-Smith and colleagues speak of IBL as a pedagogy that allows 'students to experience the processes of knowledge creation' (Spronken-Smith et al. 2007, 2). Discussion of the value of this kind of objective is often linked to the need for epistemic fluency in contemporary knowledge work (Goodyear and Ellis 2007; Goodyear and Zenios 2007).

Some authors have also associated IBL with the goal of developing students' skills in communication and collaboration. For instance, Justice et al. wrote of developing students' oral and written communication and collaborative learning skills (Justice et al. 2007), while the Boyer Commission (1998, 13) wrote of the 'skill of communication that is the hallmark of clear thinking as well as mastery of language'.

In short, authors have associated IBL with a variety of educational objectives, including the conceptual, procedural, metacognitive, affective, epistemic, and social. Our research provides an opportunity to see whether university teachers also attribute such a wide variety of educational objectives to IBL, and which kind of objectives feature prominently in their descriptions.

\section{Research questions and method Research questions}

Against the background presented above, this study addresses the following questions:

(1) What are the principal forms of learning tasks that university teachers consider to be 'inquiry-based'? What are the characteristics of each form of IBL task?

(2) What kinds of educational objectives do university teachers associate with IBL?

(3) Are there disciplinary and other contextual differences and similarities in the distribution of forms of IBL, and in their associated educational objectives?

\section{Data collection}

To address the research questions, we conducted a survey with academics from three universities in Australia. Since IBL, and some of its forms, might be held to be more common in research-intensive than in other universities, we decided to pick one 
university at random from each of three contrasting types identified by Marginson and Considine (2000): 'Sandstones' (most research intensive), 'Gumtrees' and 'Unitechs' (least research intensive).

After seeking permission from heads of schools or departments, all teaching academics from the three universities were invited via email to participate in the survey. The invitation began with a short introduction about the research project, and a brief note stating that we used 'inquiry-based learning' as a broad term which encompasses 'all forms of educational activity that give a central place to students' investigative work'. Respondents who did not feel they had designed or implemented inquirybased learning tasks were asked to say so, or simply reply with a blank email.

The survey then asked the following questions: 1) 'Please describe an inquiry-based learning task that you have set for your students' and 2) 'Thinking about this specific task, what do you hope students will learn from it?' The survey also asked for some contextual information relating to the course in which the IBL task was set: the number of students, the title of the course, discipline, and level of education (undergraduate or postgraduate).

\section{Participants}

A total of 1791 teaching academics from the three universities were invited to participate in the study. A reminder email was sent two weeks after the original invitation; a second reminder was sent a week after the first. A total of 276 academics replied indicating that they did not use IBL, while 224 emailed us with a description of their IBL task and its associated educational objectives. This represents a response rate of $28.9 \%$ (500 of 1791). Table 2 describes the participants' university and academic discipline, classified using Biglan's typology (Smart and Elton 1982), and also the level of education in which the inquiry task/course was offered.

\section{Data analysis}

Content analysis (Neuendorf 2002) was performed to code the data in terms of type of inquiry, type of educational objective, whether the task involves group work, temporal scale (whether the task spans more than one lecture session), whether the inquiry is

Table 2. University affiliation, discipline and education level (valid $n=224$ ).

\begin{tabular}{llcc}
\hline Participant profile & & Count & $\%$ \\
\hline University & 'Sandstone' & 85 & $38 \%$ \\
affiliation & 'Unitech', & 89 & $40 \%$ \\
& 'Gumtree' & 50 & $22 \%$ \\
Disciplinary & Pure-soft (social sciences and humanities) & 45 & $21 \%$ \\
cluster & Pure-hard (natural sciences and mathematics) & 27 & $12.5 \%$ \\
& Applied-soft (education, business, social work, & 89 & $41 \%$ \\
& journalism, law, design) & & \\
& Applied-hard (engineering, computer science, health & 55 & $25.5 \%$ \\
& sciences) & & \\
Education level & 152 & $71 \%$ \\
& Undergraduate & 48 & $23 \%$ \\
& Postgraduate & 13 & $6 \%$ \\
\hline
\end{tabular}


expected to produce new knowledge, and whether the outcomes of the inquiry are disseminated. Associations/dependencies between categorical variables were examined using the Chi-square test.

The coding schemes for types of inquiry and educational objectives were developed inductively by the first author. This was an iterative process: tentative categories were constructed based on systematic comparisons of the first 30 cases. These tentative categories were then applied to the rest of the data. In this process, definitions of some of the categories were modified and refined. The outcome was a coding scheme that describes the category labels, definitions, and representative examples from the data. This coding book was discussed with the second author, and was once again applied to code the whole data set.

To ensure coding reliability, the third author (who was not involved in the construction of the coding scheme) independently coded approximately $10 \%$ of the data. Calculation of Cohen's Kappa indicated good inter-rater agreement for all variables: types of inquiry $(\mathrm{K}=.81 ; p<.001)$; educational objectives $(\mathrm{K}=.75 ; p<.001)$; group work $(\mathrm{K}=1.00 ; p<.001)$; temporal scale $(\mathrm{K}=.95 ; p<.001)$; production of new knowledge $(\mathrm{K}=.90 ; p<.001)$; and dissemination $(\mathrm{K}=.95 ; p<.001)$.

\section{Findings}

\section{Principal forms of IBL tasks}

The content analysis procedure identified eight forms of IBL tasks. Table 3 gives brief descriptions and examples of each.

Some forms of inquiry tasks were reported more often than others; in particular, Simplified Research and Enactment of Practice in combination account for almost $60 \%$ of the tasks in our sample. However, we do not wish to make strong claims about the relative frequencies of different forms of inquiry. Aside from the potentially non-random nature of our sample, some inquiry forms (e.g. Role Playing or Discussionbased Inquiry) may be less frequently reported in this study simply because they are not considered to be instances of IBL by some teachers.

Instead, we wish to draw readers' attention to two dimensions that underlie the forms of IBL tasks found in this study: (a) content/practice and (b) use-orientation. The first dimension (content/practice) has to do with the focus of the inquiry activity: whether on content, i.e. the disciplinary concepts and bodies of knowledge, or on skills and practices that are part of roles that students may need to perform in their future professions (including, in some cases, as a researcher/academic). The second dimensionuse-orientation - is adopted from Stokes' (1997) typology of research. In our context, use-orientation concerns the output of the inquiry task; that is, whether there is an emphasis on practical application of the output of the task. For example, a use-inspired task may be described as an exercise that aims to address practical problems or produce solutions to specific problems. In contrast, a task which is not use-inspired can be described as being uncommitted or indifferent to any specific practical problems. Placing the content/practice and use-orientation dimensions on orthogonal axes creates a four-part space that parsimoniously organises the types of inquiry tasks observed in this study (Figure 1).

Using the typology in Figure 1, we can see that Scholarly Research is similar to Simplified Research in that neither is typically use-inspired. The two differ, however, on whether the focus is on content or on practice. Descriptions of Scholarly 
Table 3. Forms of IBL tasks.

\section{IBL form}

Scholarly Research: These tasks require students to formulate questions (although the broad topic may be given by the instructor) and to collect the empirical data to address those questions. These tasks are closest to the kinds of research in which academics typically engage.

2 Simplified Research: These tasks are simplified or narrower versions of Scholarly Research. The tasks mimic research that academics typically conduct, but students are only required to perform some aspects of the data collection and analysis. The research questions are pre-specified, and methods and analytic frameworks are usually provided through associated lectures and/or readings.

3 Literature-based Inquiry: As its name suggests, these tasks require students to conduct a review of the scientific literature pertaining to a given topic or concept. The tasks do not involve empirical data collection. The outcomes are typically reported in a written form, but sometimes students are simply asked to verbally present their literature review results.
Examples

'The students must decide on an individual research topic in local history, from which they develop research questions or aims (I assist in refining this to something do-able in the time and with the resources available). They then use these primary sources and any others they wish to gather, plus secondary sources, to write a short history on their research project.' (N12, UG, History, 20 students).

'The students are to obtain a data set, ask some statistically based questions (their choice) about the data and use statistical methods to answer their questions. The students are to summarise their work in a short report. Students may work in teams of up to three students.' (N43, UG, Statistics, 210 students).

'Students are given three sets of DNA sequences and need to use the computational tools and databases they have learnt about to discover the respective functions of the proteins. They are not told which tools to use, and the third of the sequences requires some detective work (I do give a hint)' (W14, UG, Biomedicine).

'Interview somebody you know who has a job - this could be a family member, a flat-mate, a friend, or a colleague or boss. Using one process theory of motivation (goal-setting, expectancy or equity theories), analyse their current levels of motivation. Using the same theory, identify areas for improving their motivation' (W01, UG, Management, 380 students).

'Students were provided with a scientific reference for a journal article. They were asked to obtain the article either electronically or physically using library database resources. The article pertained to an equine disease. A guideline was provided to the students with regard to how to summarise and extract the most important information within the article' (N16, UG, Veterinary Science, 44 students).

'Asked to undertake a systematic review on a question of their choice.' (W16, UG, Psychology, 39 students).
Freq $(\%)^{*}$

$23(10.7 \%)$ 
Table 3. (Continued).

4 Discussion-based Inquiry: Tasks that fall into this category are organised around teacher-led or group discussions. The discussions can be online or face-to-face, and can be more or less structured (e.g. the more structured tasks involve a debating script). The tasks may include students conducting independent research (e.g. a literature search), but the discussion is the organizing feature of the task.

5 Applied Research: These tasks are similar to Simplified Research in that students are required to collect some data to address questions or problems (which are typically specified or suggested by the lecturer). The difference is that Applied Research has a much more practical flavour: the outcomes of the activity are intended to address practical issues and problems.
'... students take part in an online debate, selecting one side of an argument (from among a number of issues) and being required to post and respond. Students are in smaller groups of 10 to 12 for these activities. A learning task later in the semester is to apply the foundational concepts to research related to their professional interests.' (E19, Social Sciences, PG, 40 students).

'Each team of students makes a presentation lasting 15 minutes either for or against a particular proposition and then has another five minutes to counter the opposing case. The propositions that I put to them are designed to get the students to research widely into the topic, discuss it at length within their group and develop arguments to counter those of the opposing team' (E23, UG, Economics).

'Students are required to research their organisational environment and identify key processes, tools and strategies for the introduction and implementation of social and environmental sustainability in their companies (most of them work full-time, many in senior management positions). The report must contain a wellresearched, well argued case for the introduction of sustainability in the organisation and recommendations based on their research.' (E06, PG, Management, 18 students).

'... [Students] had to research the issues surrounding transport, energy, food and waste in residential dwellings in NSW and then work out how they could deliver a 'car free household', a 'zero waste household' or a 'food producing household'. They worked in teams following a process of research, synthesis and communication. When they had come up with a range of design solutions, they had to pitch these ideas as if to a funding body, seeking start-up funding for further development'(E80, UG, Engineering, 580 students). 
Table 3. (Continued).

IBL form

6 Simulated Applied Research: These tasks are similar to Applied Research, in that the outcomes of the activity should address practical problems and issues. The difference is that tasks in this category present students with made-up scenarios or data, and do not require students to plan and conduct their own data collection. These tasks are often, but not always, described as 'case-based', or 'problem-based'.

7 Enactment of Practice: In these tasks, students carry out inquiry in order to enact roles that are regarded as important in the relevant profession. The tasks typically require students to either provide service to real or imagined clients (e.g. education students teaching a class, medical students giving clinical consultations, etc.), or produce/create tangible artefacts (e.g. draft novels for creative writing students, lesson plans for education students, tax reports for accounting students, etc.).
Examples

Freq $(\%)^{*}$

$19(8.8 \%)$

Students are given several case scenarios related to professional practice, ethical behaviour and clinical reasoning during practicums. Students discuss these case scenarios in small groups and use a problem solving framework to plan appropriate action or intervention related to the given scenario. Students feedback and discuss their findings and plans for intervention with the large group.' (E43, UG, Occupational Therapy, 75 students).

'Students are given a copy of the case study, about the construction of a conference centre. The centre has several serious problems acoustics, room sizes and AV equipment. Students are asked to identify the causes of the problems, working through the management of the project to see where the decisions were made that led to the unsatisfactory outcome. They are also asked how the remedial work should be managed, bearing in mind the commitments already made for the use of the centre' (E59, PG, Management, 50 students).

'Students come to a rural town for a period of three weeks. They work together initially with a local mentor to find stories with a broad health theme that are suitable for publication in the local media. They interview people, attend functions, get feedback from the journalists and radio announcers about what is of interest to the Editor and then research and write stories to a deadline. They also take the photographs and pre-record the interviews for broadcasting' (W20, UG and PG, Journalism, 9 students).

'This activity involved creating a webquest which is an Internet supported problem-based activity that usually involves group work. Creating a webquest involves developing knowledge of web design and management; evaluating and selecting useful websites to support curriculum areas; developing activities that support group work and problem based learning along with developing activities that foster creativity' (N23, UG, Education, 110 students). 
Table 3. (Continued).

$$
\text { IBL form }
$$

8 Role Playing: Role Playing can be considered to be a specific form of Enactment of Practice. Role Playing tasks require students to provide service in a role-play situation. As with Enactment of Practice, Role Playing tasks focus on practicing skills that are part of professional roles.

'students work in triads (one acting as client; one acting as counsellor; one acting as observer) with the addition of a professional counsellor overseeing the sessions. After each session, all parties provide feedback on the process. These sessions are digitally recorded and students use these sessions in a later reflective practice activity where they identify their strengths and weaknesses as well as areas for professional growth.' (N49, PG, Counselling, 70-100 students).

'After the two hour lecture we held a workshop for an hour where the class of 35 was divided into groups of three and each group was given six scenarios to work through. The scenarios were worked through one at a time with one student being the patient presenting a prescription, another being the pharmacist dispensing the prescription and the third student observing... Then the next student would have the opportunity of being the 'pharmacist' and so on until they had each been the pharmacist twice, the patient twice and observed twice.' (W11, PG, Pharmacy, 35 students).

9 Other: Two inquiry tasks - both in physics - required students to solve short quantitative problems. These were described so briefly that we found it difficult to classify them further.

'Solve all the exercises in chapters 1 to 11 in John Townsend's "Introduction to Modern Quantum Mechanics" at about one chapter per three lectures per week.' (W23, UG, Physics, 30 students).

'I was giving to student a set of problems for self-assessment after every three to four lectures. I think it helped students to get feeling that they are "growing up" and understand the course.' (E21, UG, Physics, 15 students). 


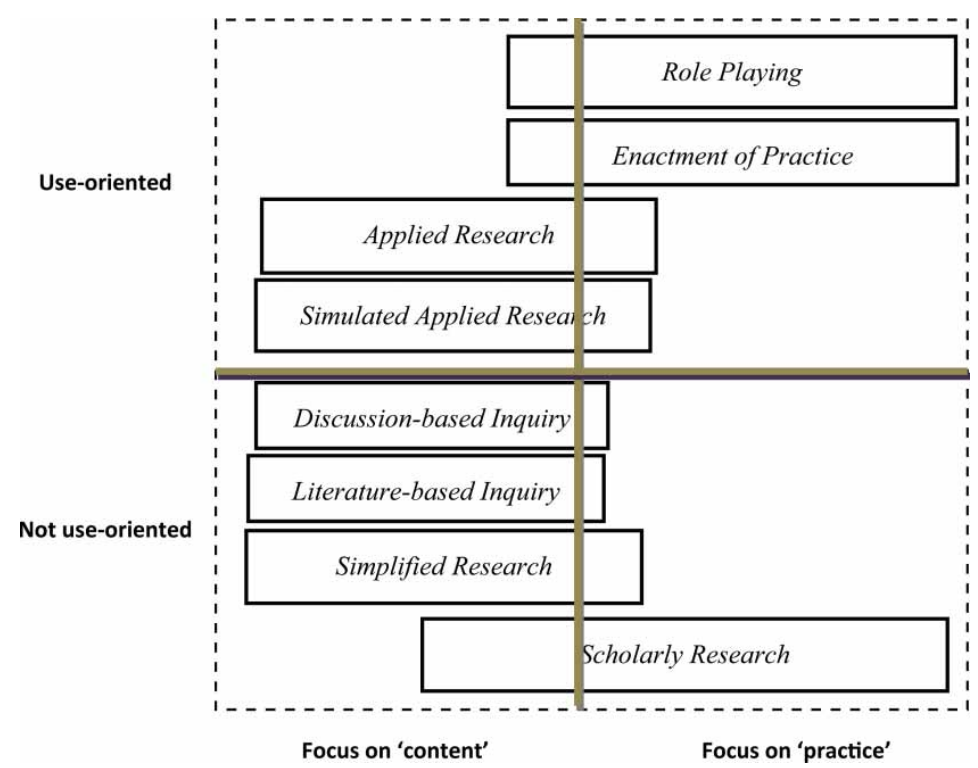

Figure 1. Typology of IBL tasks.

Research tasks in our data do not typically mention specific disciplinary concepts; rather, they focus on general research skills and processes, such as developing research questions, the collection and analysis of data, and reporting of findings. For example, one task in a social science course was simply described as 'Design, implement and evaluate a research project based on their own work/life interests' (E47), while a task in a microbiology course was described as 'a project' that included 'a literature review, lab work in an academic's or senior researcher's lab, and a final written project report and short seminar' (W84). (Note: 'W84' means this quote is from respondent 84 at University W. Readers wishing to obtain a copy of the de-identified data should contact the corresponding author.)

In contrast, descriptions of tasks classified as Simplified Research more often mention domain concepts/theories and/or research methods/techniques that students need to use. A task in a physiology course, for instance, required students to record 'resting membrane potentials of single toad muscle cells' to see if the data fits the prediction of a specific theory (N04). In another task, students of cultural studies had to use theories discussed in class to analyse and observe the impact of globalisation in a specific location (W27).

Applied Research (and Simulated Applied Research) tasks are similar to Simplified Research tasks in that both focus on the use and acquisition of disciplinary concepts. Descriptions of these tasks typically mention specific concepts or theories that are relevant to the question/problem. However, descriptions of Applied Research tasks are more contextualised in, or related to, practical problems or issues. For instance, business students may collect information on a company that faces problems related to workplace discrimination and then propose a way to resolve the issue. Or, medical students may be tasked with discussing a summary of a patient's clinical information, researching the topic, and proposing possible interventions.

Enactment of Practice tasks, like Applied Research tasks, are also concerned with practical application of knowledge. However, the focus is more on practice, i.e. performing some professional roles or aspects of the students' future profession. Although these 
Table 4. Some features of different forms of IBL task.

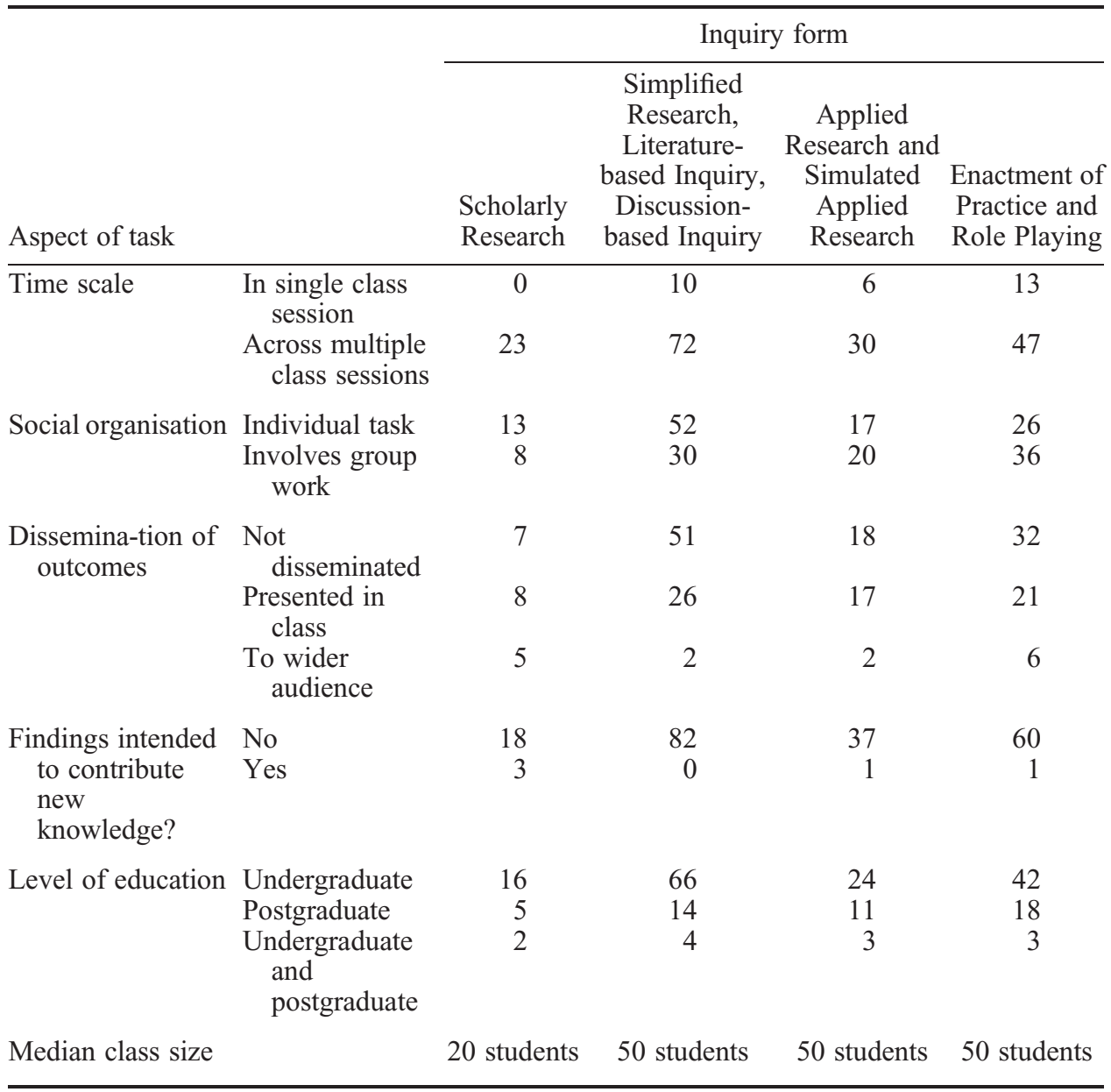

Note: Numbers represent raw frequencies (not percentages).

tasks necessarily involve the use of concepts/theories, their descriptions rarely mention them. Prototypical examples include clinical practicums for clinical psychology or medical students, teaching practicums for education students, composing novels or poems for literature students, programming software for computer science students, and so on.

The forms of IBL also differed in some other ways (see Table 4). Scholarly Research was employed in smaller classes (median $=20$ students), compared to other forms of IBL (median $=50$ students). Scholarly Research tasks were also more likely to require students to disseminate findings to audiences beyond the class community. Although all forms of IBL were likely to be performed across multiple class sessions, this was especially true for Scholarly Research tasks. Tasks that are use-oriented (Applied Research and Enactment of Practice) were more likely to involve group work, compared to tasks that are not use-oriented (Scholarly Research and Simplified Research). 
Table 5. Learning goals associated with IBL tasks (valid $\mathrm{N}=222$ ).

\begin{tabular}{lrc}
\hline Learning goals & $\mathrm{n}$ & $\%$ \\
\hline Topic/domain knowledge & 128 & $58 \%$ \\
Professional skills & 80 & $36 \%$ \\
Research/methodological skills & 74 & $33 \%$ \\
Tacit professional insights & 44 & $20 \%$ \\
Collaboration/team work skills & 36 & $16 \%$ \\
Critical thinking \& self regulated learning skills & 27 & $12 \%$ \\
Communication/presentation skills & 24 & $11 \%$ \\
Epistemological knowledge & 26 & $12 \%$ \\
Affective goals: efficacy and motivation & 23 & $10 \%$ \\
Personal belief & 11 & $5 \%$ \\
Identity-related goals & 2 & $1 \%$ \\
\hline
\end{tabular}

\section{Educational objectives associated with IBL}

What do university teachers expect students to learn through inquiry? Eleven different learning goals were identified in the data (see Table 5). The first and most frequently mentioned learning goal was to acquire and/or apply domain-or topic-specific knowledge. Most respondents described this goal in terms of deep understanding, as opposed to memorization or retention of information. Some respondents described deep understanding as being reflected in the ability to use theories as tools to address problems. For example, a task in business/management was intended to develop students' ability to 'apply the appropriate theory or theories to explain why organizations made the changes to their structure' (E45). Other respondents described this goal in terms of synthesizing or integrating theories and concepts presented in other courses or in previous lectures.

Two other frequently-mentioned goals are developing research skills and professional skills. Research skills refer to the ability to formulate questions, search and review the scientific literature, and collect and analyse data. Professional skills refer to skills which are seen to be important for the practice of the student's future profession (and vary somewhat from profession to profession). For example, a task in management intended students to 'understand how to write a Managing Diversity Policy' (E25). A task in a design course intended students to 'develop/design a game concept that has a coherent rationale and contextual setting, and how to articulate this through documenting design decision and outcomes' (E18).

An interesting type of learning goal is described here as developing students' tacit knowledge/insights. This refers to knowledge of disciplinary or professional practices that may often be implicit and not considered to be part of the explicitly-taught domain knowledge (for a wider discussion, see Sternberg and Horvath 1999). For example, a task in a pharmacy course in which students had to role-play in several counseling scenarios was intended to develop students' 'expectation of imperfect counseling on the first go' - i.e. that they should not expect their first attempt at counseling to be perfect (W11). An inquiry task in business was to help students 'to be aware of the need to be vigilant, especially with a successful organization' (W13), while a task in visual arts was intended to help students realise 'that visual information is very difficult to isolate from processes of judgment...' (W15). 
Another interesting learning goal targets students' epistemological understanding. This goal refers to knowledge about the structure, sources, and justification of knowledge in a discipline or profession. Epistemological understanding is not about the ability to collect and analyze data - which would be classified here under 'research skills' - but the knowledge that underlies those abilities. For example, one goal of a task in history was to 'understand the nature of historical evidence' (N12). A task in an education course was meant to develop students' understanding of the 'ontological and epistemological assumptions and the way these relate back to research questions and to what can be found/claimed' (N40; emphasis added). Another task in a hydrology course was designed to help students' see 'how knowledge is created in research' (N15).

Some respondents mention goals related to changing or developing aspects of students' personal beliefs. As an example, one goal of a task in a health science course was to 'encourage them [students] to identify and interrogate any preconceived ideas/stereotypes they might have around Aboriginal people and those who live in remote areas' (W6). Another task from a health science course was intended to develop students' 'better understanding of the outside and personal influences on their perceptions of mental health patients.' (N26).

Identity-related goals were mentioned only by two respondents. From a sociocultural perspective (Lave and Wenger 1991), seeing oneself as becoming a member of a community of practice is a central aspect of learning. It is quite surprising that so few identity-related goals were mentioned, because one would expect such goals to be closely related to forms of inquiry that emphasise professional practice (of which we found plenty in this study). Moreover, identity-related goals should be relatively easy to articulate (e.g. by simply saying 'get students to see themselves as a future "X", where X stands for a profession, including as a researcher/academic).

As listed in Table 5, other learning goals relate to motivation and confidence, collaboration and communication skills, and also critical thinking and self-regulated learning skills (e.g. learning how to learn, monitoring one's own understanding, time management).

\section{IBL across disciplines, university types, and level of study}

There was no association between forms of inquiry and type of university $\left(\chi^{2}[6]=\right.$ 4.124; $p=.65$ ). Relating level of study to forms of inquiry (Table 4) seems to suggest that that Simplified Research is less common in the postgraduate courses; however, this association was not statistically significant $\left(\chi^{2}[3]=4.1 ; p=.253\right)$. Forms of inquiry were associated with disciplinary clusters $\left(\chi^{2}[9]=34.81 ; p<.001\right)$. Scholarly Research tasks were more likely to be found in the pure as opposed to applied disciplines; and especially in the pure-soft disciplines (the social sciences and humanities). In contrast, both Applied Research and Enactment of Practice tasks were more likely to be observed in the applied disciplines, especially in the appliedhard cluster (engineering, computer science, and health sciences). Simplified Research, Literature-based Inquiry, and Discussion-based Inquiry tasks were distributed more evenly across the four disciplinary clusters (see Table 6).

Associations between some learning goals and disciplinary clusters were also found. Acquiring/applying domain knowledge was more common in the pure-hard (natural sciences and mathematics) and applied-soft (education, business, law, design) disciplines $\left(\chi^{2}[3]=15.14 ; p=.002\right)$. Developing research skills was mentioned more frequently in the pure disciplines, but especially in the pure-hard cluster $\left(\chi^{2}[3]=\right.$ 
Table 6. Forms of IBL in different disciplinary clusters.

\begin{tabular}{|c|c|c|c|c|c|}
\hline \multirow[b]{2}{*}{ Disciplinary cluster } & \multicolumn{4}{|c|}{ Forms of IBL tasks } & \\
\hline & $\begin{array}{l}\text { Scholarly } \\
\text { Research }\end{array}$ & $\begin{array}{c}\text { Simplified } \\
\text { Research, } \\
\text { Literature- } \\
\text { based Inquiry, } \\
\text { \& Discussion- } \\
\text { based Inquiry }\end{array}$ & $\begin{array}{c}\text { Applied } \\
\text { Research \& } \\
\text { Simulated } \\
\text { Applied } \\
\text { Research }\end{array}$ & $\begin{array}{c}\text { Enactment } \\
\text { of Practice } \\
\text { \& Role } \\
\text { Playing }\end{array}$ & Total \\
\hline $\begin{array}{l}\text { Pure-soft (social sciences } \\
\text { and humanities) }\end{array}$ & $9(20 \%)$ & $22(50 \%)$ & $3(7 \%)$ & $11(23 \%)$ & 45 \\
\hline $\begin{array}{l}\text { Pure-hard (natural sciences } \\
\text { and mathematics) }\end{array}$ & $6(24 \%)$ & $16(64 \%)$ & $1(4 \%)$ & $2(8 \%)$ & 25 \\
\hline $\begin{array}{l}\text { Applied-soft (education, } \\
\text { business, social work, } \\
\text { journalism, law, design) }\end{array}$ & $5(6 \%)$ & $31(37 \%)$ & $19(22 \%)$ & $30(35 \%)$ & 85 \\
\hline $\begin{array}{l}\text { Applied-hard (engineering, } \\
\text { computer science, health } \\
\text { sciences) }\end{array}$ & $3(5 \%)$ & $15(27 \%)$ & $16(29 \%)$ & $22(39 \%)$ & 56 \\
\hline Total & $23(11 \%)$ & $84(40 \%)$ & $39(18 \%)$ & $65(31 \%)$ & 211 \\
\hline
\end{tabular}

$11.48 ; p=.009)$. Tacit knowledge was cited slightly more often in the pure-soft disciplines $\left(\chi^{2}[3]=8.49 ; p=.037\right)$. In contrast, developing professional skills was much more frequently mentioned in the applied disciplines $\left(\chi^{2}[3]=19.36 ; p<.001\right)$.

\section{Discussion and conclusion}

The study was conducted to uncover and map variations in inquiry tasks that university teachers employ. We identified eight principal forms or variants of inquiry tasks, ranging from tasks that closely resemble research that academics perform, to simplified and applied versions of research, and to tasks that ask students to enact aspects of professional roles. These eight forms of inquiry could be organised further into a $2 \times 2$ space by considering whether a task focuses on 'content' (i.e. disciplinary bodies of conceptual knowledge) or 'practice' (either the practice of research or a profession), and whether the outcome of the inquiry is expected to address practical problems. We also found that university teachers associate inquiry with a wide range of educational objectives, which include the cognitive, metacognitive, affective, social, and epistemic aspects of learning. Some understandable disciplinary differences were found, such as that forms of inquiry which are use-oriented could be found more frequently in the applied disciplines. We now discuss three subsidiary issues on which our findings shed some light.

\section{What is the common thread between the various forms of inquiry tasks? What does this say about how university teachers conceptualise inquiry-based learning?}

University teachers used various terminologies to describe IBL tasks. As described above, we can also find qualitatively different tasks that are regarded as being inquiry-based. Despite this diversity in both language and types of tasks, by and large the tasks proposed as being inquiry-based conform to the core elements of IBL described in the literature (e.g. Levy et al. 2010; Oliver 2008; Prince and Felder 2006). Firstly, most if not all the tasks involve 'active learning' in the sense that students are required to engage in some kind of activity that goes beyond listening to 
lectures or receiving direct instruction. And secondly, most of the tasks involved activities that are problem/question-driven, as opposed to topic-driven. Even the narrower forms of inquiry identified in this study, such as Literature-based and Discussionbased Inquiry, can be designed in ways that are problem-driven. For instance, students in a biotechnology course had to review the literature to examine whether there is a market for a certain enzyme, while students in an economics course had to write an essay about how a game theory could shed light on a practical issue.

\section{Concerns about the practical/logistical difficulty of incorporating IBL in undergraduate education}

The findings above show that IBL is practised in both undergraduate and postgraduates courses in a wide range of disciplines. Forms of inquiry were evenly distributed across the three types of universities (Sandstone, Gumtree, and Unitech). Furthermore, IBL is not restricted to small classes: in our sample, only $8.5 \%$ of the courses are small (10 students or fewer), while the overall median class size is 50 students. This indicates that IBL is incorporated in the mainstream curriculum, with inquiry tasks embedded in courses that do not only cater for a select segment of students.

Our findings may seem to be inconsistent with Jewell and Brew's (2010) study, which found that extracurricular undergraduate research/inquiry experiences are mostly found in science and engineering, and mainly target an elite segment of the student population. The differing findings stem from the fact that Jewell and Brew were describing a specific form of inquiry task (similar to what we call Scholarly Research), while our study adopted a broader definition of IBL. Thus, if we consider a wider variety of tasks, there seem to be more opportunities for incorporating inquiry into undergraduate and postgraduate coursework curricula.

\section{Concerns that inquiry tasks often do not resemble authentic research and do not provide opportunities for students to experience 'knowledge building'}

Several researchers have voiced concerns about the (lack of) authenticity in some tasks that go under the banner of inquiry-based learning. Brew $(2010,142)$, for example, noted that 'many efforts to integrate research and teaching stop short of engaging students ... in the research culture of schools and departments' (emphasis added). Levy and Petrulis $(2011,10)$ also found that most of the first-year undergraduate social science students they interviewed did not describe their inquiry experiences as oriented towards creating new knowledge.

Our findings indicate that these concerns have a legitimate basis. Among the forms of inquiry we observed, perhaps only Scholarly Research can be regarded as close to the kinds of research that academics engage in, while Simplified Research and Applied Research might be seen as only being 'research-like'. Furthermore, only five tasks mentioned anything about inquiry as something intended to build new knowledge. Indeed, many of the tasks in our sample focused on existing knowledge, or solving problems that were framed by tutors or 'clients'. Hence, in terms of the IBL framework proposed by Levy and colleagues, many of these tasks fall into the 'identifying mode' of inquiry. Goodyear and Ellis (2007) noted a similar absence of knowledge-building activities in their analysis of interviews with university teachers.

Nonetheless, we would like to point out some encouraging aspects of our findings. We do so by disentangling 'learning' (personal construction of one's own knowledge) from 
engagement in 'knowledge building' (Bereiter 2002). Bereiter's conception of knowledge building refers to the use of concepts and theories as tools to perform knowledge work (understood as working in the abstract world of public knowledge, to refine explanations of phenomena, improve ideas, etc.). If we take a looser view than Bereiter's, the outcome of a knowledge-building activity need not be knowledge that is new to humankind.

From this perspective, then, although tasks labelled here as Simplified Research or Applied Research do not address open-ended problems and are not intended to build knowledge that is new to the world, this does not mean they cannot involve knowledge-building activities. Indeed, many of these tasks require students to use conceptual tools (even if these are specified in advance by the teacher) to perform aspects of knowledge work: e.g. to look at a familiar phenomenon from a theoretically-grounded perspective, compare how different theories shed different lights on the same problem, and so on. This is illustrated in the examples of Simplified Research, Literaturebased Research, Discussion-based Research, and Applied Research provided in Table 3. To be clear, we are not claiming that all, or even most, of the tasks in our present data involve authentic knowledge-building activities. What we would like to say is simply that tasks which seem to bear little resemblance to academic research can be designed in a way that enables students to experience aspects of knowledgebuilding or authentic knowledge-work.

In conclusion, our findings show that IBL is indeed practiced in a wide range of disciplines, at both undergraduate and postgraduate coursework programs, in smaller and larger classes, and in universities which are more and less research intensive. We have shown that underlying the diversity of language and tasks regarded as IBL there is a limited number of distinct task forms and a broad conception of inquiry that is shared by university teachers.

\section{Acknowledgements}

We gratefully acknowledge the funding provided by the Australian Research Council through a Discovery grant (DP0988334, 'Learning through Inquiry in Higher Education'). We thank the many academics who contributed their time to respond to our survey and also Rachel SpronkenSmith, Phil Levy and Angela Brew for advice, ideas and encouragement.

\section{References}

Andrews, M., and P.R. Jones. 1996. Problem-based learning in an undergraduate nursing programme: A case study. Journal of Advanced Nursing 23, no. 2: 357-65.

Bereiter, C. 2002. Education and mind in the knowledge age. Mahwah, NJ: Lawrence Erlbaum Associates.

Boyer Commission. 1998. Reinventing undergraduate education: A blueprint for America's research universities. Stony Brook: State University of New York.

Brew, A. 2003. Teaching and research: New relationships and their implications for inquirybased teaching and learning in higher education. Higher Education Research \& Development 22, no. 1: 3-18.

Brew, A. 2010. Imperatives and challenges in integrating teaching and research. Higher Education Research \& Development 29, no. 2: 139-50.

Ellis, R.A., P. Goodyear, M. Brillant, and M. Prosser. 2007. Student experiences of problembased learning in pharmacy: Conceptions of learning, approaches to learning and the integration of face-to-face and online activities. Advances in Health Sciences Education 13, no. 5: 675-92.

Ellis, R.A., G. Marcus, and R. Taylor. 2005. Learning through inquiry: Student difficulties with online course-based material. Journal of Computer Assisted Learning 21: 239-52. 
Goodyear, P., and R.A. Ellis. 2007. The development of epistemic fluency: Learning to think for living. In Transforming a university: The scholarship of teaching and learning in practice, ed. A. Brew and J. Sachs, 57-68. Sydney: Sydney University Press.

Goodyear, P., and M. Zenios. 2007. Discussion, collaborative knowledge work and epistemic fluency. British Journal of Educational Studies 55, no. 4: 351-68.

Healey, M. 2005. Linking research and teaching: Exploring disciplinary spaces and the role of inquiry-based learning. In Reshaping the university: New relationships between research, scholarship and teaching, ed. R. Barnett, 67-78. Maidenhead, UK: McGraw Hill/Open University Press.

Healey, M., and A. Jenkins. 2009. Developing undergraduate research and inquiry. Research report to the higher education academy. York, UK: Higher Education Academy.

Helle, L., P. Tynjala, and E. Olkinuora. 2006. Project-based learning in post-secondary education - Theory, practice and rubber sling shots. Higher Education 51: 287-314.

Jewell, E., and A. Brew. 2010. Undergraduate research experience: Programs in Australian universities. Strawberry Hills, Australia: Australian Learning and Teaching Council. http://www.mq.edu.au/ltc/altc/ug_research/files/Brew_MQFellowship_UGprograms_ report2010.pdf.

Justice, C., J. Rice, and W. Warry. 2009. Academic skill development - Inquiry seminars can make a difference: Evidence from a quasi-experimental study. International Journal for the Scholarship of Teaching and Learning 3, no. 1: 1-23.

Justice, C., J. Rice, W. Warry, S. Inglis, S. Miller, and S. Sammon. 2007. Inquiry in higher education: Reflections and directions on course design and teaching methods. Innovation in Higher Education 31: 201-14.

Kolodner, J.L. 2006. Case-based reasoning. In The Cambridge handbook of the learning sciences, ed. R.K. Sawyer, 225-42. Cambridge: Cambridge University Press.

Kolodner, J.L., J.H. Gray, and B.B. Fasse. 2003. Promoting transfer through case-based reasoning: Rituals and practices in learning by design classrooms. Cognitive Science Quarterly 3: $183-232$.

Lave, J., and E. Wenger. 1991. Situated learning: Legitimate peripheral participation. Cambridge: Cambridge University Press.

Levy, P., S. Little, P. Mckinney, A. Nibbs, and J. Wood. 2010. The Sheffield companion to inquiry-based learning. Brook Hill, UK: Centre for Inquiry-based Learning in the Arts and Social Sciences (CILASS), The University of Sheffield. http://www.shef.ac.uk/ibl.

Levy, P., and R. Petrulis. 2011. How do first-year university students experience inquiry and research, and what are the implications for the practice of inquiry-based learning? Studies in Higher Education. First published online February 24. DOI: 10.1080/ 03075079.2010 .499166$.

Marginson, S., and M. Considine. 2000. The enterprise university: Power, governance and reinvention in Australia. New York: Cambridge University Press.

Mills, J.E., and D.F. Treagust. 2003. Engineering education - Is problem-based or project-based learning the answer? Australasian Journal of Engineering Education. http://www.aaee.com. au/journal $/ 2003 /$ mills_treagust03.pdf.

Neuendorf, K.A. 2002. The content analysis guidebook. London: Sage.

Oliver, R. 2008. Engaging first year students using a web-supported inquiry-based learning setting. Higher Education 55: 285-301.

Prince, M., and R. Felder. 2006. Inductive teaching and learning methods: Definitions, comparisons, and research bases. Journal of Engineering Education 95, no. 2: 123-38.

Prince, M., and R. Felder. 2007. The many faces of inductive teaching and learning. Journal of College Science Teaching 36, no. 5: 14-20.

Rogers, M.A.P., and S.K. Abell. 2008. The design, enactment, and experience of inquiry-based instruction in undergraduate science education: A case study. Science Education 92, no. 4: 591-607.

Savery, J.R. 2006. Overview of problem-based learning: Definitions and distinctions. The Interdisciplinary Journal of Problem-based Learning 1, no. 1: 9-20.

Scardamalia, M., and C. Bereiter. 2006. Knowledge building: Theory, pedagogy, and technology. In The Cambridge handbook of the learning sciences, ed. R.K. Sawyer, 97-118. Cambridge: Cambridge University Press. 
Smart, J.C., and C.F. Elton. 1982. Validation of the Biglan model. Research in Higher Education 17, no. 3: 213-29.

Spronken-Smith, R., T. Angelo, H. Matthews, B. O'Steen, and J. Robertson. 2007. How effective is inquiry-based learning in linking teaching and learning. Paper presented at the International Colloquium on International Policies and Practices for Academic Enquiry, April 19-21, in Marwell, Winchester, UK.

Spronken-Smith, R., and R. Walker. 2010. Can inquiry-based learning strengthen the links between teaching and disciplinary practice? Studies in Higher Education 35, no. 6: 723-40.

Spronken-Smith, R., R. Walker, J. Dickinson, G. Closs, J. Lord, and T. Harland. 2011. Redesigning a curriculum for inquiry: An ecology case study. Instructional Science 39, no. 5: 721-35.

Sternberg, R.J., and J. Horvath, eds. 1999. Tacit knowledge in professional practice: Researcher and practitioner perspectives. Mahwah, NJ: Lawrence Erlbaum Associates.

Stokes, D. 1997. Pasteur's quadrant: Basic science and technological innovation. Washington, DC: Brookings Institute. 